\title{
Effect of Amritasattvadi yoga in Parinama shula
}

\author{
Research article
}

\section{Veena. G. Rao ${ }^{1 *}$, Manjunath. N.S}

1. Asst.professor, Dept.of Roganidana, 2. Lecturer, Dept.of Swastavritta, JSS Ayurveda Medical College, Lalithadri pura, Mysore 28

\begin{abstract}
Owing to faulty food habits and stressful life, duodenal ulcer/parinama shula has become a very common health problem. Acute and chronic gastritis can end up with duodenal ulcer. It can be effectively treated through Ayurveda, the science of life. Objectives: Literary review of duodenal ulcer and parinama shula with its treatments \& to study the effect of Amrita sattvadi yoga in patients of parinama shula/duodenal ulcer. Methods: 20 patients with confirmed clinical diagnosis of parinama shula/duodenal ulcer were administered Amrita sattvadi yoga orally in a dose of 2 gms twice daily with ghee \& honey for 45 days under proper pathya \& apathya. Results: From the statistical analysis of the recorded data it is evident that, in $70 \%$ of patients epigastric pain $\&$ hunger pain relieved completely within 15 days of treatment. The results are significant even in relieving the other clinical features.
\end{abstract}

Key words: Amrita sattva, parinama shula, duodenal ulcer, shanka bhasma, narikela lavana.

\section{Introduction:}

Parinama shula or duodenal ulcer is a very common disorder owing to stressful life. Because of westernization of food, habits and culture, individuals are prone to develop this condition. As recurrence of the ulcer is quiet common even after surgery, an effective Ayurvedic formulation has to be established. So, the effect of "Amritasattvadi yoga" is studied in patients of parinama shula.

Aims \& objectives:

i) To study the effect of "Amritasattvadi yoga" in patients of parinama shula.

* Corresponding Author:

Veena. G. Rao

Asst.professor,

Dept.of Roganidana,

JSS Ayurveda Medical College,

Lalithadri pura, Mysore 28,

Mob: +919844549152,

E-mail:- drveenagrao@yahoo.in

\section{Literary review:}

Parinama shula is one among the ten types of udarashula explained by Hareeta. Aggravated vata either gets avarana by kaphapitta or combines with kaphapitta to produce shula in the udara specifically during digestion of food. As per madhavakara, annadrava shula, paktidosha, paktishula and annavidahaja shula are synonyms of parinama shula. The pain gets aggravated by food prepared out of shashtika \& vreehishali and relieved by vomiting, immediately after intake of food \& after complete digestion of food (hunger pain)(1).

$$
\text { It is vataja, when }
$$

adhmana(abdominal distension), atopa (gurgling sounds) \& vibandha(constipation) dominate. When hrit-kanta dahalthroat \& retrosternal burning), trishna(thirst) dominates along with aggravation of shula by katu amla lavana rasa(pungent, sour\&salt food), then it is of pittaja variety. Dominance of 
hrillasa(nausea) and chardi(vomiting) indicates kaphaja variety.

Parinama shula can be paralleled with duodenal ulcer as it matches with its nidana panchakas. Duodenal ulcers are more common than gastric ulcers. Most duodenal ulcers occur in the first part of duodenum. A chronic ulcer penetrates mucosa \& muscle coat leading to fibrosis.

Helicobacter pylori infection is important factor in the development of duodenal ulcer. NSAIDs, alcohol, cigarette smoking, reflux of bile with poor functioning of pylorus sphincter are the etiological factors. O blood group, Stress has been implicated in predisposing duodenal ulcer.

The peak incidence is now in a much older age group than previously, still more common in men. Patients develop periodic epigastric pain, especially hunger pain. Epigastric pain during night hours awakens the patient from sleep. Spicy, fried $\&$ hard to digest food are aggravating factors. Heart burn, nausea, loss of appetite $\&$ vomiting are the other features.

Presence of both anterior \& posterior ulcer is referred as "kissing ulcers". Anterior ulcer tends to perforate leading to acute abdomen $\&$ posterior ulcer tends to bleed resulting in black tarry stools known as malena. Pyloric stenosis due to fibrosis of repeated ulcers \& malignancy (rarely) are the complications of duodenal ulcers.

Endoscopy (gastroduodenoscopy) is the chief investigation in the diagnosis of duodenal ulcer. CLO test is to determine the presence of H.Pylori infection. If necessary, multiple biopsy to rule out malignant changes.

"Amritasattvadi yoga" is a combination of four ayurvedic drugs. Among them 'Amrita sattva' and 'godanti bhasma' are jwarahara \& are indicated in pittaja vyadhis. 'Shankha bhasma' and 'nareekela lavana' are indicated specifically in parinaman shula.

\section{Materials \& methods:}

Materials taken for the study was "Amritasattvadi yoga."

$\begin{array}{ll}\text { Amrita sattva } & 2 \text { parts } \\ \text { Godanti bhasma } & 2 \text { parts } \\ \text { Shankha bhasma } & 2 \text { parts } \\ \text { Nareekela lavana } & 1 \text { part }\end{array}$

Amrita sattva: Mature guduci is cut into small pieces and made into a pulp. This is put in water, stirred well and sieved through cloth. The fibers are removed; water is added and stirred a number of times till the deposit becomes white. Water is then decanted and the sattva is dried under the sun (2).

Godanti bhasma: Purification of godanti is done by giving swedana with nimbu rasa for one hour thirty minutes (half yama). This godanti is placed in sharava samputa and subjected to gaja puta. The colour of bhasma will be white (3).

\section{Shankha bhasma:}

Small pieces of shankha are bundled in a piece of cloth. Swedana in dola yantra with kanjika is given for three hours. When cool, the shankha pieces are washed with warm water. Purified shankha is placed in sharava samputa. Sandhi lepa is done and dried, gajaputa is given. This process is repeated twice (4).

\section{Nareekela lavana:}

A fully-ripe fruit is taken, the shell is removed and a hole is made at the top of the coconut. Powdered lavana is put through the hole till the water in the coconut rises to the level of the hole. The coconut is then covered by clay smeared cloth in three consecutive layers and dried. This is put into a puta of 10-15 cowdung cakes. When cool, the charred coconut 
containing lavana is powdered in a khalva (5).

These four drugs are mixed in above said proportion in the "Amritasattvadi yoga."

Sampling: 20 Patients with confirmed clinical diagnosis of parinama shula i.e. duodenal ulcer was taken for the study.

\section{Inclusion Criteria:}

i) Patients with pratyatma lakshana of parinama shula i.e. udara shula during digestion (bhukte jeeryati yat shulam i.e. pain 30 to $45 \mathrm{~min}$ after intake of food).

ii) Hunger pain \& night pain in the epigastric region.

iii) Above said pain with or without other features of parinama shula explained in our classics.

iv) Irrespective of sex \& occupation

v) Age between 16 to 70 years

\section{Exclusion criteria:}

i) Patients with complications of duodenal ulcer like pyloric stenosis, perforation, haemorrhage \& malignancy.

ii) Duodenal ulcer associated with other systemic disorders.

\section{Diagnostic criteria:}

i) Purely clinical diagnosis was done

\section{Investigations:}

Blood $-\mathrm{Hb} \%$ \& Stools for occult blood

\section{Study design:}

As it is an observational study, all the selected 20 patients diagnosed on the above parameters were administered "Amritasattvadi yoga" orally in a dose of $2 \mathrm{~g}$ twice daily with $5 \mathrm{ml}$ cow's ghee and $2.5 \mathrm{ml}$ of honey as anupana $1 \mathrm{hr}$ before food for 45 days. Patients are advised to have pathyas like milk, ghee and light fresh warm non spicy foods. They are also advised to restrain from stress, smoking, alcohol, fried spicy food, sour fermented food \& drinks, excess sweets, potato, green peas, horse gram like foods.

\section{Assessment Criteria:}

For the purpose of assessment of treatment, the symptoms \& signs were scored $0,1,2 \& 3$. Scores were fixed according to the severity of the clinical features.

i) Epigastric pain during digestion of food (bhukte jeeryati yat shulam)

a) 0 - no pain

b) 1 - occasional mild pain

c) 2 - moderate pain during digestion of every meal

d) 3 - severe pain during digestion of every meal

ii) Epigastric tenderness

a) 0 - no tenderness

b) 1 - mild tenderness sometimes

c) 2 -persistent moderate tenderness

d) 3 - persistent severe tenderness

iii) Hunger pain

a) 0 - no pain

b) 1 - occasional mild pain

c) 2 - moderate pain during hunger after every meal

d) 3 - severe pain during hunger after every meal

iv) Malabaddhata (constipation)

a) 0 - normal bowels

b) 1 - hard bowels once/twice a day

c) 2 - hard bowels once in two days

d) 3 - hard bowels once in 3 days or more than that

v) Adhmana (distension of abdomen)

a) 0 - no distention

b) 1 - sometimes mild distention

c) $2-$ moderate persistent distention

d) 3- severe persistent distention

iii) Hrit kanta daha (heart burn)

a) 0 - no heart burn

b) 1 - mild occasional heart burn 
c) 2 - moderate heart burn \& throat burning

d) 3 - severe heart burn \& throat burning

vii) Tikta amla udgara (sour\& bitter eructation)

a) 0 - no eructation

b) 1 - mild eructation sometimes

c) 2 - moderate eructation even on sitting

d) 3-severe persistent eructation

viii) Hrillasa (nausea)

a) 0 - no nausea

b) 1 - mild nausea occasionally

c) 2 - persistent moderate nausea

d) 3 - persistent severe nausea

ix) Chardi (vomiting)

a) 0 - no vomiting

b) 1- 2 to 3 times vomiting/day

c) 2 - 4 to 5times moderate vomiting/day

d) $3-5$ or more than 5 times vomiting/day

Data regarding all the above said clinical features were collected on the $1^{\text {st }}$ day of study and end of every week for
6 weeks while the patients on medications. Two follow-ups were done on $56^{\text {th }} \& 70^{\text {th }}$ day i.e. end of first and second week after completion of medications.

These data's were subjected to statistical analysis by applying students unpaired ' $t$ ' test. $P$ value was calculated by referring to Fischer's table at the corresponding level of degree of freedom and based on these, results were interpreted.

\section{Observations:}

It is observed that mental stress has major role in the predisposition of duodenal ulcer. Hereditary factor was observed in 4 patients. 3 patients were alcoholic. Frequent intake of tea and coffee were observed in 8 patients. Among 20, 13 patients had vatapittaja deha prakriti \& 15 had rajasika manasa prakriti. 8 patients had acute features \& 12 had chronic features. vataja type was observed in 11 patients, pittaja in $7 \&$ kaphaja in 2 patients.

\section{Results:}

Table 1: showing the statistical analysis of mean clinical features score before treatment $\&$ after 42 days of treatment.

\begin{tabular}{|l|l|l|l|l|l|l|}
\hline Clinical features & $\begin{array}{c}\text { B.T } \\
\text { M+S.D }\end{array}$ & $\begin{array}{c}\text { A.T } \\
\text { M+S.D }\end{array}$ & S.E & $\begin{array}{l}\text { Mean } \\
\text { Difference }\end{array}$ & T value & P value \\
\hline $\begin{array}{l}\text { Epigastric pain } \\
\text { during digestion }\end{array}$ & $2.25+0.44$ & $0.00+0.00$ & 0.099 & 2.25 & 22.650 & $<0.0001$ \\
\hline $\begin{array}{l}\text { Epigastric } \\
\text { tenderness }\end{array}$ & $1.75+0.72$ & $0.10+0.31$ & 0.131 & 1.65 & 12.567 & $<0.0001$ \\
\hline Hunger pain & $1.55+0.83$ & $0.05+0.22$ & 0.199 & 1.50 & 7.5498 & $<0.0001$ \\
\hline malabaddhata & $1.05+0.60$ & $0.05+0.22$ & 0.145 & 1.00 & 6.8920 & $<0.0001$ \\
\hline adhmana & $0.95+0.51$ & $0.20+0.41$ & 0.143 & 0.75 & 5.2517 & $<0.0001$ \\
\hline Hritkanta- daha & $1.95+0.83$ & $0.40+0.50$ & 0.153 & 1.55 & 10.099 & $<0.0001$ \\
\hline Tiktaamla udgara & $1.40+0.99$ & $0.15+0.37$ & 0.190 & 1.25 & 6.5713 & $<0.0001$ \\
\hline hrillasa & $0.50+0.61$ & $0.25+0.55$ & 0.143 & 0.25 & 1.7506 & $<0.0961$ \\
\hline Chardi & $0.20+0.41$ & $0.00+0.00$ & 0.092 & 0.20 & 2.1794 & $<0.0421$ \\
\hline
\end{tabular}


From the statistical analysis of the recorded data it is evident that, in $70 \%$ of patients epigastric pain \& hunger pain relieved completely within 15 days of treatment. Where as in another $16 \%$ \& $14 \%$ of patients it took $3 \& 4$ weeks respectively for the complete subsidence of pain. Relief from other clinical features were observed in due course within 4 to 6 weeks of treatment. From the above statistical data it is evident that, the results are highly significant in relieving the clinical features of parinama shula. Recurrence of pain was not observed in any patients up to the last follow-up i.e. $70^{\text {th }}$ day.

\section{Conclusion:}

"Amritasattvadi yoga" can be effectively used in the management of parinama shula i.e. duodenal ulcer.
Absolute subsidence of clinical features in patients of duodenal ulcer suggests its ulcer healing property. This effect is fortified by its anupana ghee and honey.

\section{References:}

1. Madhavakara. Madhukosha Sanskrit Comm, Madhava Nidana. 22 ed. Chaukambha Sanskrit Samsthana; Varanasi; 1993. 427p.

2. Lakshmipati Shastri Vaidya. Yogaratnakara, 4ed. Chaukhambha Sanskrit Samsthana; Varanasi; 1988. 205p.

3. Sri Sadananda Sharma. Rasatarangini, 11ed. Chaukhambha Sanskrit Samsthana; Varanasi; 2004. 238p.

4. Sri Sadananda Sharma. Rasatarangini, 11ed. Chaukhambha Sanskrit Samsthana; Varanasi; 2004. 17-19p.

5. Govinda Das. Bhaishajya ratnavali, 3ed. Chaukhambha Sanskrit Series; Varanasi; 1969. 81p. 